\title{
Abundance of Meiofauna and Physical-Chemical Parameters as Water Quality Indicator
}

\author{
Muh Sri Yusal1*, Muh Aris Marfai ${ }^{2}$, Suwarno Hadisusanto 3 and Nurul Khakhim ${ }^{2}$ \\ ${ }^{1}$ Environmental Science, Multidisciplinary Graduate School, Universitas Gadjah Mada \\ 2Faculty of Geography, Universitas Gadjah Mada \\ ${ }^{3}$ Faculty of Biology, Universitas Gadjah Mada \\ J. Teknika Utara, Pogung, Yogyakarta, 55281, Indonesia. \\ Email: msriyusal.ugm@gmail.com
}

\begin{abstract}
The zone of Losari Coast is an icon of Makassar city, however increase activity of surrounding communities causes a decrease in the water quality. Meiofauna is an effective benthic organism used as an indicator of water quality. This study assessed the meiofauna abundance and physical-chemical parameters as water quality indicator in the Losari Coast, Makassar. The sampling method in this study was purposive sampling. The resuts showed that total meiofauna abundance identified was 66791 indv. $\mathrm{m}^{-2}$, composed of 12 phylum and 91 species or genera. Stations at the estuary of the Jeneberang and Tallo River are two sites with high level of abundance, this condition allows presence of organic contaminants triggers the high growth of meiofauna in these locations. Dissolved Oxygen is below its supposed level in waters. Acidity, phosphate and nitrate content at some of research stations exceed the threshold of their allowed presence in waters set by Indonesia government. Ostracoda, oligochaeta, polychaeta, tunicata and ciliophora are phylums with a high level of abundance, because the phylum has high adaptability to pollutant. Good water quality is indicated by a variety of biota living in the waters, the range of diversity and uniformity indices shows that meiofauna species are categorized highly diverse and evenly distributed. The dominance index shows that there is no species was dominant, except stations around Losari reclamation project. Temperature, current velocity, depth, brightness, salinity, $\mathrm{pH}, \mathrm{DO}$, nitrateseawater, and phosphate-seawater correlate with meiofauna abundance. The results as a consideration for the management or monitoring of coastal environments.
\end{abstract}

Keywords: abundance, water indicator, Losari coast, meiofauna, pollutant

\section{Introduction}

Coastal areas store an enormous amount of biodiversity and, therefore, require preservation, as a result of the integration of several interconnected, dynamic, and productive ecosystems. The aquatic resources are parts of the natural resources that are most widely used by the community. However, the exploitation remains to be neglectful of their sustainability, reducing their functions and qualities in the environment. The pollutants that directly or indirectly enter the coastal area endanger not only the lives of all biota but also the entire natural resources of coastal ecosystems, for instance, the threats of degradations of mangroves, seagrasses, coral reefs, and aquatic animals (Elyazar et al., 2007; Dahuri et al., 2008).

The coastal zone of Losari Beach is one of the coastal areas in South Sulawesi that have great potential coastal and marine resources. Increased human activity or development in its surroundings deteriorates its condition to the threshold of alarming depletion of resource and ecosystem (Coremap, 2006). Some environmental parameters, e.g., physical and chemical characteristics, change slowly towards the negative category. Several studies show that the contents of dissolved heavy metals, namely lead $(\mathrm{Pb})$, copper $(\mathrm{Cu})$ and cadmium (Cd), have slowly exceeded the water quality standard and categorized the waters as polluted (Monoarfa, 2002; Werorilangi et al., 2011; Jaya et al., 2012; Setiawan, 2014).

A series of human activities upstream, such as house-scale and gold-crafting industries, densely populated housing, the constructions of hotels, restaurants, and cafes, tourist activities, hospitals, aquaculture, and agricultural practices, is the main cause of the entry of pollutants into the waters. It greatly affects water quality and threatens the existence of organisms that live on and under the water surface. Aquatic physical-chemical parameters are control factors that have direct or indirect 
influence on the speed of metabolic rate and the aquatic organisms proliferation. Koropitan et al. (2009) stated that environmental physical factors has an important role in the speed of metabolic rate and respiration of aquatic biota so that need to dissolved oxygen gas is increasing. This shows that higher the influence of physical factors in the aquatic environment such as temperature, salinity, and the partial pressure of dissolved gases, therefore the dissolved oxygen value decreases in water. Likewise with aquatic chemical parameters that indirectly affect the process of aquatic organisms growth and development, such as in terms of the formation of energy and proteins in cell metabolic processes (Nicholson et al., 2006).

In general, aquatic biota that can indicate water quality is benthic organisms, which are a community of microscopic to macroscopic invertebrates. This community lives and remains in seafloor environment for a long time. The use of benthic animals in water quality assessment is more effective and efficient, and it can function as a comparative data to the measurement of the physical and chemical characteristics of an aquatic environment (Arroyo et al., 2004; Hariyati, 2007; Armenteros et al., 2009; Giere, 2009; Riena et al., 2012; Assy et al., 2013; Pratomo et al., 2013; Septiani et al., 2013).

A benthic animal that can effectively indicate water pollution is meiofauna. Meiofauna defines a collection of organisms larger than microfauna but smaller than macrofauna. With a size range of 63$1,000 \mu \mathrm{m}$, these organisms can pass through a 1$\mathrm{mm}$ mess, but they are retained by a $45-\mu \mathrm{m}$ mesh (Moodley et al., 2000; Montagna et al., 2002; Gwyther \& Fairweather, 2002; Gwyther, 2003; Giere,
2009). Meiofauna is a biological component that can be used as an indicator of changes in water quality. There are some advantages of using it as a water quality bioindicator, namely: (1) this community of organisms has different sensitivity to various types of pollutants and provides a quick reaction to changes in waters; (2) due to its low mobility, it is easily influenced by the state of its surrounding environment; and (3) it is easy to capture and identify (Giere, 2009; Moreno et al., 2011; Mirto et al., 2012; Alves et al., 2013). Therefore, this study aims to assess the abundance of meiofauna and environmental physical-chemical parameters as water quality indicator at Losari coast, Makassar.

\section{Materials and Methods}

The study was carried out in July-October 2017 at Losari coast, which stretches from the north to the south of Makassar City, South Sulawesi. This area represents the intensive human activity and development in the surrounding environment. Nine (9) sampling sites were located nearby tourist attraction areas, hotels, beach reclamation projects, aquaculture practices, agricultural land in the upper part of the river, hospitals, ports, industrial areas, house-scale industries, and densely populated housing. See Figure 1.

This study employed purposive sampling method, i.e., the selection of samples based on specific objectives, on the aquatic substrate as the habitat of meiofauna. The study area was determined based on the previous research that described the Losari coast as an area contaminated by hazardous chemicals and metal contents.

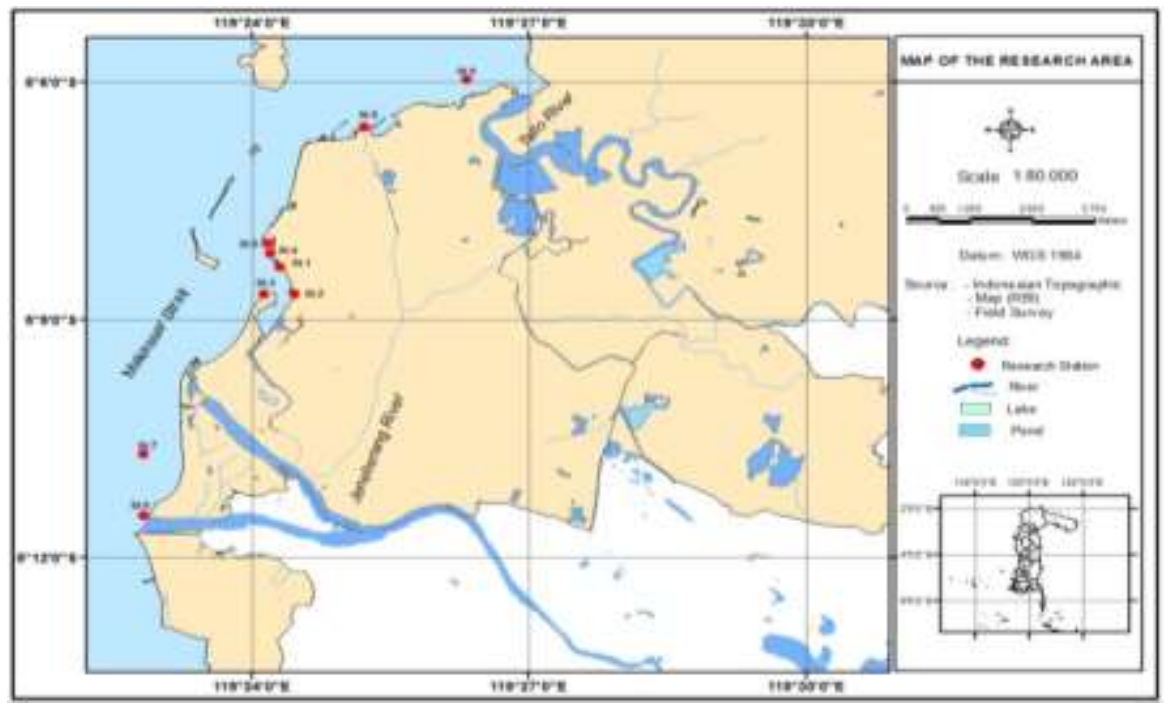

Figure 1. Map of sampling sites at Losari coast of Makassar City, South Sulawesi, Indonesia 
The density of meiofauna on the Losari Coast was determined using formula by Krebs (1989). The diversity index in a community was calculated using the Shannon-Wiener's Index (Odum, 1994). Diversity Index can identify the extent of water pollution or determine the water quality of an area or region. Water quality classification based on the diversity index (Odum, 1994). The Dominance Index was measured with the formula of the Simpson's Index of Dominance (Krebs, 1989). Uniformity or evenness index was calculated using the formula of the Hilis Evenness Index (Krebs, 1989).

One-way ANOVA was applied which is aimed to examine the significant differences in the abundance of meiofauna at the research stations (Mirto et al., 2012). Tukeys test was done following those that significantly different. Principal Component Analysis determined the abiotic variables (i.e. physical and chemical parameters) that affected the abundance of meiofauna.

\section{Results and Discussion}

\section{Abundance and composition of meiofauna}

Total meiofauna abundance discovered during the research was 66,791 indv. $\mathrm{m}^{-2}$, consisting of 91 species or genera from 12 phyla (Figure 2 and Table 1.). Station I had a total meiofauna abundance of 3,209 indv. $\mathrm{m}^{-2}$, while Station II, III, and IV had 3,185 indv. $\mathrm{m}^{-2} ; 4,746$ indv. $\mathrm{m}^{-2}$; and 5,100 indv. $\mathrm{m}^{-2}$, respectively. Station $V$ had the lowest meiofauna abundance, i.e. 2,415 indv. $\mathrm{m}^{-2}$, whereas Station VI had the highest one, i.e. 16,239 indv. $\mathrm{m}^{-2}$. As for the remaining Station VII, VIII, and IX, the total meiofauna abundances were 10,909 indv. m-2; 10,118 indv. $\mathrm{m}^{-2}$; and 10,870 indv. $\mathrm{m}^{-2}$, respectively. Based on the phylum, the total meiofauna abundance was as follows: Aelosomatidae (40 indv. $\left.\mathrm{m}^{-2}\right)$, Ciliophora (1,902 indv. $\left.\mathrm{m}^{-2}\right)$, Gastrotricha (555 indv. $\mathrm{m}^{-2}$ ), Gnathostomulida (258 indv. $\mathrm{m}^{-2}$ ), Nematoda (751 indv. $\left.\mathrm{m}^{-2}\right)$, Nemertina (456 indv. $\left.\mathrm{m}^{-2}\right)$, Oligochaeta (25,562 indv. $\left.\mathrm{m}^{-2}\right)$, Ostracoda $(31,945$ indv. $\left.\mathrm{m}^{-2}\right), \quad$ Polychaeta $\left(1,286 \quad\right.$ indv. $\left.\mathrm{m}^{-2}\right)$, Sarcomastigophora (595 indv. $\left.\mathrm{m}^{-2}\right)$, Tunicata $(2,905$ indv. $\left.\mathrm{m}^{-2}\right)$, and Turbellaria (536 indv. $\left.\mathrm{m}^{-2}\right)$. In numerical order, the composition of the density of meiofauna was as follows: Ostracoda (47.828\%), Oligochaeta (38.272\%), Tunicata (4.349\%), Ciliophora (2.848\%), Polychaeta (1.925\%), Nematoda (1.124\%), Sarcomastigophora (0.891\%), Gastrotricha (0.831\%), Turbellaria $(0.8309 \%)$, Nemertina (0.683\%), Gnathostomulida (0.386\%), and Aelosomatidae $(0.060 \%)$ (Figure 2. and 3.).

The highest abundance was found at Stations $\mathrm{VI}$, VII, and IX, while the lowest one was identified at
Stations V and II. Compared with other phyla, Ostracoda, Oligochaeta, Ciliophora, and Tunicata had a high density, whereas Aelosomatidae had a low density. There was a significant difference in the average abundance of meiofauna in several research stations, as evident from $\mathrm{F}=7.584$ and $P=$ 0.00 . These results showed that the abundance of meiofauna phylum in every station was significantly different from each other or, in other words, without similarities. Tukey's test resulted in three groups of meiofauna inhabiting the Losari coast (Table 2. and 3.). The results of the one-way ANOVA affirmed the differences in the densities of meiofauna phylum at each station.

In general, Losari Beach is inhabited by true meiofauna, which is benthic organisms whose entire life cycle are in the form of meiofauna living at the bottom of the waters (permanent meiofauna). Ostracoda, Oligochaeta, and Ciliophora can adapt to habitats containing the accumulation of organic and inorganic contents from the nearby land and aquatic environment. These phyla can live in a variety of habitat conditions, such as muddy environments or surfaces covered with fine sand or coarse sand. Ciliophora has cilia covering some or all parts of its body as an organ that helps its movement to find food or adapt to an unfavorable environment. In a polluted environment, Oligochaeta is equipped with cysts on the walls of its body to anticipate anaerobic conditions (lack of oxygen) at the bottom of waters. Meanwhile, Ostracoda has adhesive threads to attach its body to benthic plants, sands, or other substrates (Giere and Pfannkuche, 1982; Hartmann, 1985; Rodriguez et al., 2001).

Some of the meiofauna have slender bodies and adhesive glands. Oligochaeta can even adapt to oxygen-deficient habitats using its rigid body shape with a few but large setae. The reproduction rates of Ostracoda, Oligochaeta, and Ciliophora are also high even in unfavorable environmental conditions. They can anticipate such adversities because they are hermaphrodite, bisexual, and even parthenogenic, i.e., asexual reproduction without the fertilization of two different sexes. Ciliophora can also regenerate by binary fission, i.e. direct division of the nucleic cells of the body to give rise to two cells without the fertilization of two entities with different sexes (Corliss, 1972; Fenchel, 1987; Higgins and Thiel, 1988). Tunicata can adapt to an unfavorable environment by simplifying its internal organs to a very small shape and hermaphroditic form (i.e., having multiple sex cells for reproduction). The small gonadal sex is always carried on the lower side of the body until it becomes mature and develops into new individuals at any time (Higgins and Thiel, 1988; Mirto et al., 2012). 
Stations VI, VII, and IX represent the conditions in Jeneberang and Tallo Rivers estuaries that flow directly to the Losari coast. Stations VI and IX have a high abundance of meiofauna because organic pollutants, which trigger the high growth rate of meiofauna, are transported by both rivers and washed out by rainwater from the low-lying areas to the river mouth. The same case applies to Station VII, which illustrates the condition of Tanjung Merdeka Beach as the tourist attractions in Makassar City. This area is crowded with local tourists during the holidays and even on weekdays. The constructions of tourist-supporting facilities on and around the beach, such as villas, lodges with simple to luxurious amenities, semi-permanent buildings for recreation or rest, and cafes and food stalls, have started. The development at the tourism sites also plays a major role in the entry of organic wastes into the surrounding waters. These particles can cause a high abundance of meiofauna in this region.

Station V has a very low level of abundance. It illustrates the areas around Soekarno-Hatta Port, Makassar, which is the largest port in the eastern part of Indonesia. It is characterized by intensive development activities, busy maritime traffic, and port renovation to welcome the Indonesian government's Sea Toll Road Program. Station II also has a low abundance of meiofauna. It typifies the conditions nearby the hotels, restaurants, cafes, hospitals, house-scale industries, and handicraft and gold-crafting industries. These anthropogenic activities introduce inorganic wastes, e.g., hazardous metals, to the surrounding waters and cause a fatal impact on the growth of aquatic organism (Monoarfa, 2002; Werorilangi et al., 2011; Jaya et al., 2012; Setiawan, 2014).

\section{Dominance, diversity and evenness indices}

The dominance index of meiofauna in all stations ranged from 0.0507 to 0.1178 with an average of $0.0746 \pm 0.0217$. This range is close to 0 , indicating the absence of dominant meiofauna species at each station. As for the diversity index, it ranged from 2.2653 to 3.0992 with an average of $2.8824 \pm 0.2009$. These figures represent the high diversity of the community of meiofauna inhabiting the research stations (Odum, 1994). A high diversity means that the meiofauna can adapt to disturbed and polluted environments caused by the entry of contaminants from the surrounding land or environment (Coull et al., 1992; Albuquerque et al., 2007).

The evenness index varied between 0.7860 and 0.9459 with an average of $0.8673 \pm 0.0439$. These index values are close to 1 , which indicates that the meiofauna species are diverse and evenly

Table 1. The meiofauna abundance at Losari coast, Makassar City, South Sulawesi, Indonesia

\begin{tabular}{|c|c|c|c|c|c|c|c|c|c|c|}
\hline \multirow{2}{*}{ Phyla } & \multicolumn{10}{|c|}{ Density (indv. $\mathrm{m}^{-2}$ ) } \\
\hline & ST.I & ST.II & ST.III & ST.IV & ST.V & ST.VI & ST.VII & ST.VIII & ST.IX & $\Sigma$ \\
\hline Aelosomatidae & - & - & 40 & - & - & - & - & - & - & 40 \\
\hline Ciliophora & 238 & 297 & 159 & 20 & 99 & 119 & 120 & 692 & 158 & 1902 \\
\hline Gastrotricha & 159 & 0 & 79 & 0 & 20 & 79 & 40 & 0 & 178 & 555 \\
\hline Gnathostomulida & 0 & 20 & 119 & 0 & 0 & 0 & 0 & 40 & 79 & 258 \\
\hline Nematoda & 20 & 0 & 79 & 158 & 178 & 0 & 0 & 0 & 316 & 751 \\
\hline Nemertina & 20 & 20 & 99 & 0 & 0 & 40 & 79 & 0 & 198 & 456 \\
\hline Oligochaeta & 218 & 1481 & 1402 & 1936 & 772 & 5747 & 4523 & 4583 & 4900 & 25562 \\
\hline Ostracoda & 1960 & 1168 & 1307 & 1840 & 970 & 9977 & 6007 & 4585 & 4131 & 31945 \\
\hline Polychaeta & 40 & 79 & 158 & 99 & 59 & 79 & 20 & 178 & 574 & 1286 \\
\hline Sarcomastigophora & 356 & 20 & 40 & 0 & 0 & 40 & 80 & 0 & 59 & 595 \\
\hline Tunicata & 0 & 20 & 1284 & 1047 & 158 & 79 & 40 & 0 & 277 & 2905 \\
\hline Turbelaria & 198 & 40 & 20 & 0 & 159 & 79 & 0 & 40 & 0 & 536 \\
\hline$\sum$ & 3209 & 3185 & 4746 & 5100 & 2415 & 16239 & 10909 & 10118 & 10870 & 66791 \\
\hline
\end{tabular}

Table 2. The Results of the One-way ANOVA of the meiofauna abundance along the Losari Coast

\begin{tabular}{lccccc}
\hline & Sum of Squares & Df & Mean Square & F & Sig \\
\hline Between Groups & $4.630 \mathrm{E} 7$ & 11 & 4209146.891 & 7.584 & .000 \\
Within Groups & $5.328 \mathrm{E} 7$ & 96 & 555031.012 & & \\
Total & $9.958 \mathrm{E} 7$ & 107 & & & \\
\hline
\end{tabular}




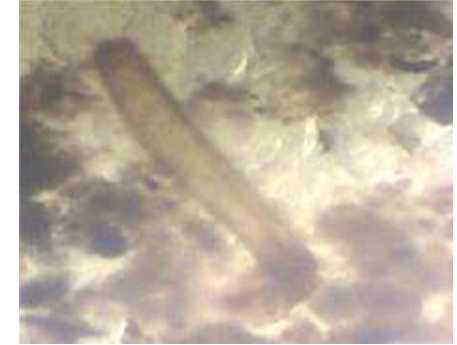

Turbellaria

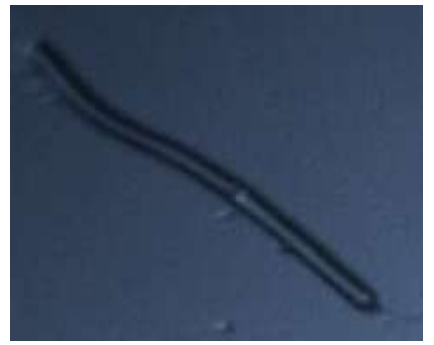

Polychaeta

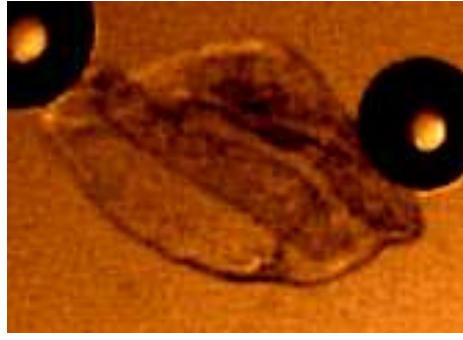

Tunicata

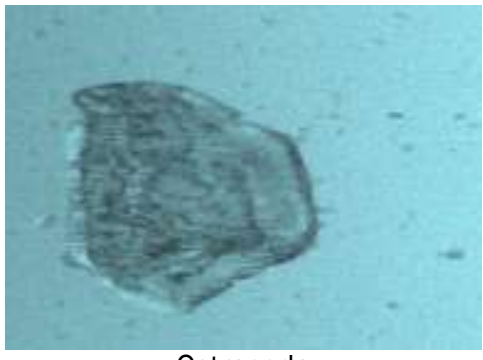

Ostracoda

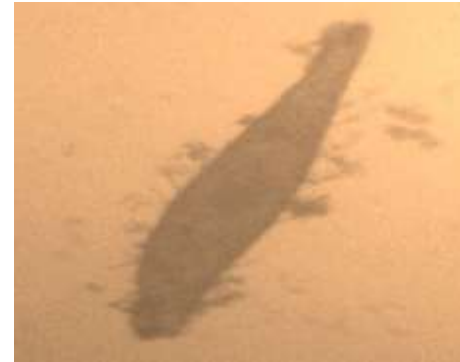

Ciliophora

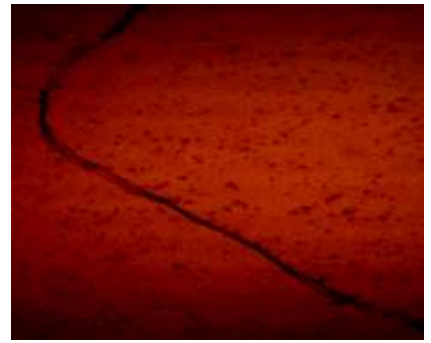

Olygochaeta

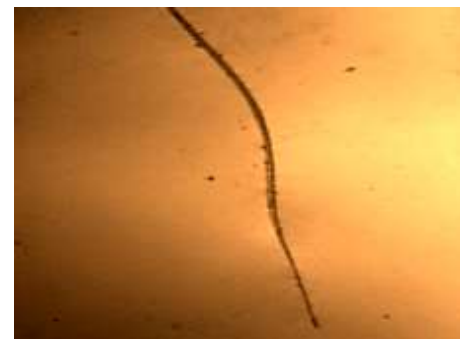

Nematoda

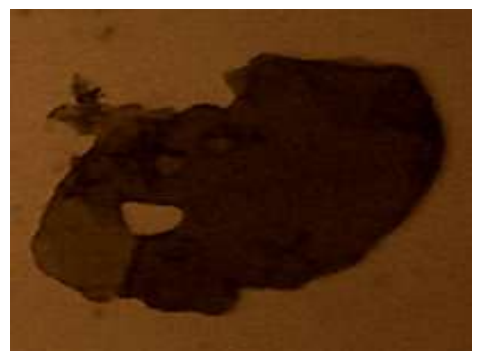

Sarcomastigophora

Figure 2. The meiofauna phyla which has high abundance in Losari Coast

distributed, or in other words, there are no dominant species at the research stations (Krebs, 1989). However, Station III is an exception. It has a low evenness index due to the presence of dominant meiofauna species. These station is dominated meiofauna are be able to adapt of disturbed environmental conditions caused by reclamation project activities.

\section{Relationship between water quality and abundance of meiofauna}

According to the Decree of the Indonesian Ministry of Environment No. 51/2004, some of the physical-chemical parameters do not meet the standards for water quality. Dissolved oxygen was below its supposed level in waters. Meanwhile, $\mathrm{pH}$ as well as phosphate and nitrate content at some of the research stations exceed the threshold of their allowed presence in waters (Table 4.).

Figure 4 show a correlation between some of the physical-chemical environmental factors, such as temperature, current velocity, depth, brightness, salinity, $\mathrm{pH}, \mathrm{DO}$, nitrate in seawater, phosphate in seawater, and the abundance of meiofauna in the study area. The relationship between these variables are positive and negative, and the contributions of 
the environmental factors to the abundance of meiofauna vary between $0.15 \%$ and $11.78 \%$ (Table 5). Seawater salinity, $\mathrm{pH}$, and phosphate are positively correlated to the abundance of meiofauna at the bottom of the waters. In other words, the higher the range of these three parameters, the higher the abundance of organisms.

Acidity $(\mathrm{pH})$ is influenced by the entry of contaminants into the waters, an acid aquatic environment (low $\mathrm{pH}$ ) potentially lead to the death of aquatic organisms. In seawater, phosphate is an abiotic parameter that is necessary for the development of meiofauna in waters. Therefore, when the phosphate content decreases, the abundance of these organisms also drops (Clavero et al., 1991; Morse, 1993). Water salinity is an environmental parameter that strongly affects the presence of meiofauna. Increased salinity interferes with the presence of meiofauna at the bottom of the waters. As well as, Aryawati et al. (2017) stated that temperature and $\mathrm{pH}$ are environmental parameters has support the growth of sea biota.

Temperature, current velocity, depth, brightness, DO, and nitrate-seawater are negatively correlated with the abundance of meiofauna in the study area. Accordingly, an increase in the range of these parameters is likely followed by a decrease in the abundance of meiofauna. Oxygen content is an important factor in the life of organisms like meiofauna. Dissolved oxygen is useful in the process

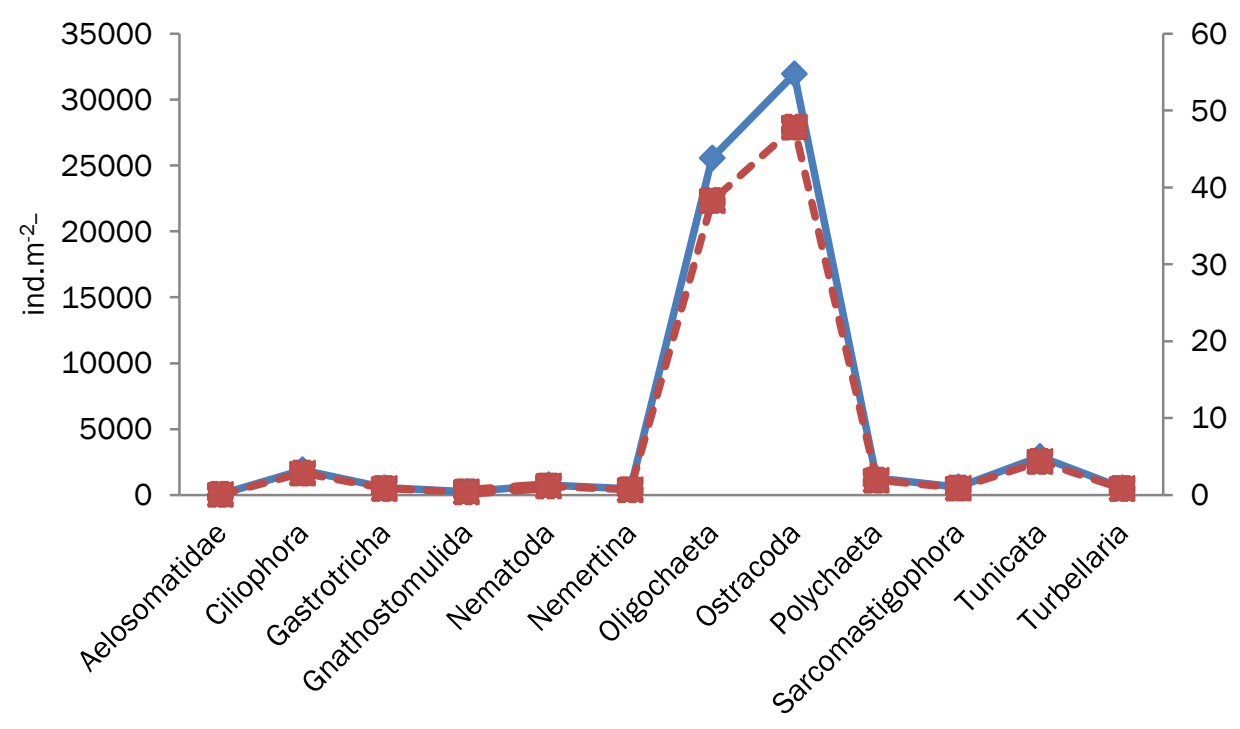

Figure 3. The composition of meiofauna phyla along the Losari Coast Note. $\stackrel{\sim}{\longrightarrow}=$ Abudance,,$-\square--=$ Composition

Table 3.Results of Tukey's test of meiofauna abundance along Losari coast, Makassar City, South Sulawesi, Indonesia

\begin{tabular}{|c|c|c|c|c|}
\hline \multirow{2}{*}{ Phylum } & \multirow{2}{*}{$\mathrm{N}$} & \multicolumn{3}{|c|}{ Tukey HSDa Subset for alpha $=0.05$} \\
\hline & & 1 & 2 & 3 \\
\hline phylum Aelosomatidae & 9 & 2.22 & & \\
\hline phylum Gnathostumulida & 9 & 11.00 & & \\
\hline Phylum Nemertina & 9 & 13.22 & & \\
\hline phylum Turbellaria & 9 & 15.56 & & \\
\hline phylum Gastroicha & 9 & 19.89 & & \\
\hline phylum Sarcomastigophora & 9 & 226.22 & 226.22 & \\
\hline phylum Nematoda & 9 & 266.33 & 266.33 & \\
\hline phylum Polychaeta & 9 & 336.67 & 336.67 & \\
\hline phylum Ciliophora & 9 & 393.56 & 393.56 & \\
\hline phylum Tunicata & 9 & 700.89 & 700.89 & \\
\hline phylum Oligochaeta & 9 & & 1389.44 & 1389.44 \\
\hline phylum Ostracoda & 9 & & & 2223.33 \\
\hline Sig. & & .699 & .056 & .433 \\
\hline
\end{tabular}


ILMU KELAUTAN: Indonesian Journal of Marine Sciences June 2019 Vol 24(2):81-90

Table 4. Physical-chemical characteristics of waters at Losari coast, Makassar City, South Sulawesi, Indonesia

\begin{tabular}{|c|c|c|c|c|c|c|c|c|c|c|}
\hline \multirow{2}{*}{ Parameters } & \multicolumn{9}{|c|}{ Research Stations } & \multirow{2}{*}{ Max. Limit* } \\
\hline & St. I & St. II & St. III & St. IV & St. V & St. VI & St. VII & St. VIII & St. IX & \\
\hline Salinity & 25 & 30 & 29 & 26 & 26 & 20 & 27 & 20 & 25 & Natural \\
\hline $\mathrm{Ph}$ & 9.98 & 7.52 & 7.48 & 7.8 & 7.42 & 7.15 & 7.7 & 7.78 & 7.98 & $7-8.5$ \\
\hline Temp. $\left({ }^{\circ} \mathrm{C}\right)$ & 30 & 28 & 31 & 28 & 32 & 33 & 30 & 32 & 33 & Natural \\
\hline Depth $(m)$ & 3.2 & 2.4 & 6 & 2 & 3 & 4 & 2.6 & 4 & 2 & - \\
\hline Current velocity $\left(\mathrm{m} \cdot \mathrm{s}^{-1}\right)$ & 0.032 & 0.08 & 0.4 & 0.1 & 0.59 & 0.68 & 0.35 & 0.42 & 0.67 & - \\
\hline Brightness (m) & 2 & 2 & 3 & 1 & 1.5 & 3.5 & 2.5 & 3.4 & 1.5 & - \\
\hline DO & 4 & 3.4 & 5 & 3.2 & 5 & 5 & 5 & 3 & 5 & $>5 \mathrm{mgL}^{-1}$ \\
\hline Phosphate-seawater & 0.03 & 0.12 & 0.0002 & 0.18 & 0.0003 & 0.005 & 0.0004 & 0.64 & 0.0024 & $0.015 \mathrm{mgL}^{-1}$ \\
\hline Phosphate-sediment & 0.02 & 0.025 & 0.019 & 0.015 & 0.018 & 0.017 & 0.013 & 0.023 & 0.023 & - \\
\hline Nitrate-seawater & 0.0006 & 0.02 & 0.0003 & 0.51 & 0.00021 & 0.09 & 0.0002 & 0.78 & 0.00023 & $0.008 \mathrm{mgL}^{-1}$ \\
\hline Nitrate-sediment & 0.0014 & 0.001 & 0.0005 & 0.0006 & 0.0012 & 0.001 & 0.0006 & 0.0006 & 0.0006 & - \\
\hline
\end{tabular}

Table 5. The Summary of the PCA: The contribution of the Physical-chemical variables (\%) to the abundance of meiofauna

\begin{tabular}{lrrrr}
\hline & \multicolumn{1}{c}{ F1 } & F2 & \multicolumn{1}{c}{ F3 } & F4 \\
\hline Abundance & 9.3351 & 0.3204 & 11.0283 & 0.5926 \\
Dominance & 15.5018 & 1.2818 & 0.2574 & 2.2129 \\
Evenness & 12.9428 & 2.4495 & 0.7741 & 6.7369 \\
Diversity & 10.8347 & 0.9757 & 6.8906 & 6.1825 \\
Phosphate-seawater & 0.1568 & 25.1152 & 1.6087 & 0.2906 \\
Phosphate-sediment & 0.0429 & 6.1403 & 1.7934 & 12.2964 \\
Nitrate-seawater & 1.4470 & 21.5619 & 0.0239 & 4.6404 \\
Nitrate-sediment & 0.0551 & 0.3321 & 0.0091 & 58.1719 \\
Salinity & 7.4806 & 3.8605 & 11.0559 & 2.1631 \\
Ph & 4.3253 & 6.5400 & 6.0891 & 0.5108 \\
Temperature & 11.7814 & 2.1903 & 6.5276 & 1.9727 \\
Depth & 8.2246 & 0.0313 & 25.6541 & 0.0261 \\
Brightness & 6.4216 & 0.0115 & 17.9144 & 2.8752 \\
DO & 0.5742 & 25.2823 & 0.1408 & 0.8765 \\
Current Velocity & 10.8760 & 3.9073 & 10.2326 & 0.4512 \\
\hline
\end{tabular}

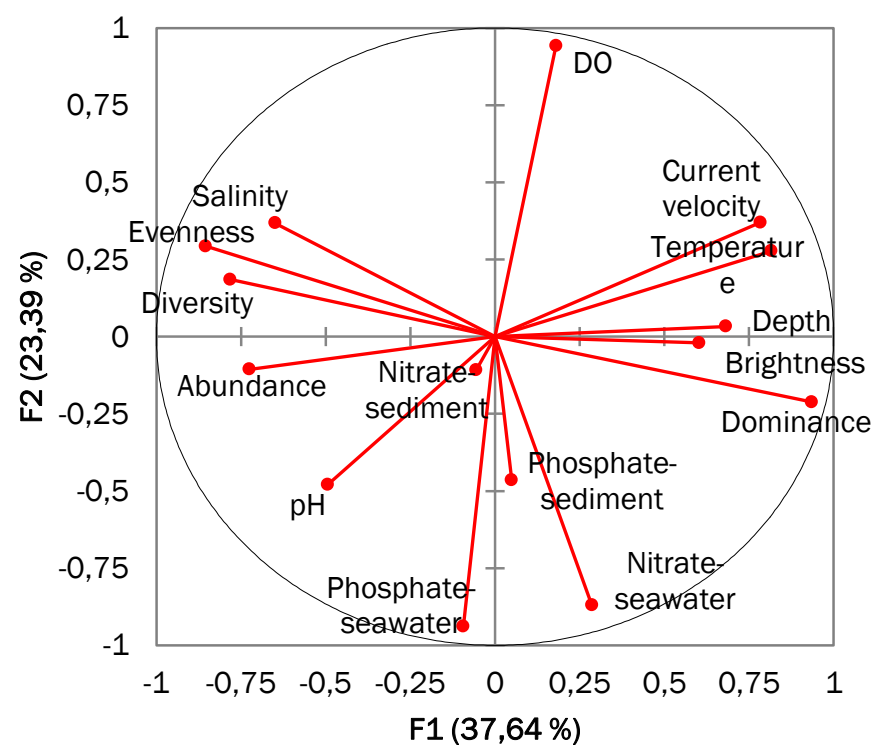

Figure 4. Output diagram of the Principal Component Analysis between the physical- chemical parameters and the abundance of meiofauna on the Losari coast, Makassar City, South Sulawesi, Indonesia 
of breathing and metabolism of meiofauna that lives in the bottom of the waters. In general, high DO content can increase the abundance of meiofauna, but some meiofauna species can live well in anaerobic conditions (Silence et al., 1993).

Nematoda, Ciliophora, Ostracoda, Gnathostomulida, Gastrotricha, and Oligochaeta are meiofauna that can live and reproduce in unfavorable environmental conditions, such as low DO content (Giere and Pfannkuche, 1982; Heip et al., 1985; Coull, 1992; Morse, 1993). The same case applies to the other parameters, namely current velocity, temperature, depth, brightness, and nitrate-seawater, which shape the abundance of meiofauna in waters. However, some meiofauna species can survive even when some of these parameters are low in the environments (Giere, 2009).

\section{Conclusion}

Ostracoda, Oligochaeta, Tunicata, and Ciliophora have a high level of abundance on the Losari coast. The research stations located around Jeneberang and Tallo Rivers estuaries have a high abundance of meiofauna. Meanwhile, the research stations nearby the port, Paotere Harbor, hotels, hospitals, restaurants, cafes, and gold-crafting industries have a low abundance of meiofauna due to the direct physical disturbances to the habitat of meiofauna and the entry of hazardous metal contents generated by the diverse anthropogenic activities into the waters. The meiofauna species on the Losari coast are highly diverse, as evidenced by the diversity index (i.e.>2). The range of the evenness index of all stations is close to 1 , indicating that the meiofauna species in the study area are very even.

\section{References}

Albuquerque, E.F., Pinto, A.P.B., Alcantara de Queiroz, P.A., \& Veloso V.M. 2007. Spatial and temporal changes in interstitial meiofauna on a sandy ocean beach of South America. Brazil. J. Oceanograp. 55(2): 121-131. doi: 10.1590/S1 $679-87592007000200005$

Alves, A.S., Adao, H., Ferrero, T.J., Marques, J.C., Costa, M.J. \& Patricio, J. 2013. Benthic meiofauna as indicator of ecological changes in estuarine ecosystems: The use of nematodes in ecological quality assessment. Ecol. Indi. 24: 462-475. doi:10.1016/j.ecolind.2012.07.013
Armenteros, M., Creagh, B. \& Gonzalez-Sanson, G. 2009. Distribution Patterns of Meiofauna in Coral Reefs from the NW Shelf of Cuba. Rev. Invest. Mar. 30(1): 37-43.

Arroyo, N.L., Maldonado, M., Perez-Portela, R. \& Benito, J. 2004. Distribution patterns of meiofauna associated with a sublittoral laminaria bed in the Cantabrian Sea (NorthEastern Atlantic). Mar. Biol. 144: 231-242. doi: 10.1007/s00227-003-1191-8

Aryawati, R., Bengen, D.G., Pratono, T. \& Zulkifli, H., 2017. Abundance of phytoplankton in the coastal waters of South Sumatera. IImu Kelautan. 22(1):31-39. doi: 10.14710/ik.ijms. 22.1.31-39

Assy, D., Widyorini, N. \& Ruswahyuni, 2013. Hubungan Kelimpahan Meiofauna Pada Kerapatan Lamun Yang Berbeda di Pulau Panjang, Jepara, J. Manag. Aqua. Res. 2(3): 226-232.

Coral Reef Rehabilitation and Management Program (Coremap), 2006. Degredasi Sumber Daya Pesisir dan Kelautan Sulawesi Selatan.

Corlis, J.O. 1972. Current Status of the international collection of ciliate type-specimens and guidelines for future contributors. Trans. Am. Microsc. Soc. 91:221-235

Coull, B.C., Creed, E.L., Esktn, R.A., Montagna, P.A., Palmer, M.A. \& Wells, J.B.J. 1992. Phylal meiofauna from the rocky inlertidal at Murrell's inlet, South Carolina. Trans. Am. Microsc. Soc. 102: 380-389.

Clavero, V., Niell, F.X. \& Fernandez, J.A. 1991. Effects of Nereis diversicolor O.F. Muller abundance on the dissolved phosphate exchange between sediment and overlying water Palmones River Estuary (S. Spain). Estuar. Coast. Shelf Scie. 33: 193-202.

Dahuri, H.R., Rais, J., Ginting, S.P. \& Sitepu, H.J. 2008. Pengelolaan Sumberdaya Wilayah Pesisir dan Lautan Secara Terpadu. Jakarta: PT. Pradnya Paramita. 326 pp.

Elyazar, N., Mahendra, M.S. \& Wardi, I.N. 2007. Impact of community activities on the level of seawater pollution in Kuta Beach, Badung Regency and environmental conservation efforts. Ecotrophic. 2(1):1-18.

Fenchel, T. 1987. Ecology of protozoa: The biology of free-living phagotropic protists. Berlin: SpringerVerlag. 197 pp. 
Giere, O. \& Pfannkuche, C. 1982. Biology and ecology of marine Oligochaeta. A Review. Oceanogr. Mar. Bio. Ann. Rev. 20:173-308.

Giere, O. 2009. Meiobenthology. The Microscopic Motile Fauna of Aquatic Sediment. 2nd edition, Berlin: Springer-Verlag. 527 pp.

Gwyther, J. \& Fairweather, P.G. 2002. Colonization by epibionts and meiofauna of real and mimic pneumatophors in a coll temperate mangarove habitat. Mar. Ecol. Progr. Ser. 229: 137-149.

Gwyther, J. 2003. Nematode assemblages from Avicennia marina leaf litter in a temperate mangrove forest in south-eastern Australia. Mar. Bio. 142: 289-297.

Hariyati, R. 2007. Distribusi dan Kemelimpahan Meiofauna di Hulu Sungai Code Yogyakarta. Bioma. 9(2): 34-37. doi: 10.14710/bioma.9.2. 34-37

Hartmann, G. 1985. Ostracoden aus der Tiefsee des Indischen Ozeans und der Iberischen see sowie von ostatlantischen sublitoralen Plateus und Kuppen. Senckenbergiana Maritima. 17(1/3: 89-146.

Heip, C., Vincx, M. \& Vranken, G. 1985. The ecology of marine nematodes. Oceanogr. Mar. Bio. Ann. Rev. 23: 399-489.

Higgins, R.P. \& Thiel, H.. 1988. Introduction to the Study of Meiofauna. Washington, D.C.: Smithsonian Institution Press. 488 pp.

Jaya, A.M., Tuwo, A. \& Mahatma. 2012. The assessment of environmental conditions and social economic change reclamation Losari Beach and Tanjung Bunga, Marine Science and Fisheries, Universitas Hasanuddin.

Koropitan, A.F., Ikeda, M., Damar, A. \& Yamanaka, Y. 2009. Influences of Physical Processes on the Ecosystem of Jakarta Bay: a Coupled PhysicalEcosystem Model Experiment. J. Mar. Sci. 66(2): 336-348.

Krebs, C.J. 1989. Ecological Methodology, New York: University of British Colombia Press. 654 pp

Mirto, S., Michele, G., Mauro, S. \& Giulia, M. 2012. Meiofauna as an indicator for assessing the impact of fish farming at an exposed marine site. Ecol. Indi.. 468-476. doi: 10.1016/j. ecolind.2011.12.015
Monoarfa, W. 2002. Dampak pembangunan bagi kualitas air di kawasan pesisir Pantai Losari Makassar. Sci. Tech. 3(3): 37-44.

Moreno, M., Semprucci, F., Vezzulli, L., Balsamo, M., Fabiano, M. \& Albertelli, G. 2011. The use of nematodes in assessing ecological quality status in the Mediterranean coastal ecosystems. Ecol. Indi. 11:328-336.

Morse, G.K., Lester, J.N. \& Perry, R., 1993. The economic and environmental impact of phosphorus removal from wastewater in the European Community. Publ. Division Selper Ltd.

Montagna, P.A., Bauer, J.E., Hardin, D. \& Spies, R. B., 2002. Vertical distribution of microbial and meiofaunal populations in sediments of natural coastal hydrocarbon seep. J. Mar. Sci. 47(3): 657-680. doi: 10.1357/0022240897850762 26

Moodley, L., Chen, G., Help, C. \& Vincx, M. 2000. Vertical distribution of meiofauna in sediments from contrasting sites in the Adriatic Sea. Clues to the role of biotic control. Ophelia. 53(3): 203212.doi:10.1080/00785326.2000.10409450

Nicholson, D., Dyhrman, S., Chavez, F. \& Pytan, A. 2006. Alkaline Phosphate Activity in the Phytoplankton Communities of Monterey Bay and San Frnacisco Bay. J. Am. Soc. Limnol. Oceanogr. 51(2): 874-883.

Odum, E.P. 1994. Fundamentals of ecology, Yogjakarta: Gadjah Mada University Press. 630 pp.

Pratomo, A., Abdillah, D. \& Agustinus, Y. 2013. Struktur Komunitas Makrozoobentos Sebagai Indikator Kualitas Perairan di Pulau Lengkang Kecamatan Belakang Padang Kota Batam Provinsi Kepulauan Riau, Jurnal Kelautan Universitas Maritim Raja Ali Haji.

Riena, N.N., Putri, W.A.E. \& Agustriani, F. 2012. Analysis of Estuary Water Quality of Belau River Bandar Lampung. Maspari J. 4(1): 116-121.

Rodriguez, J.G., J. Lopes, \& E. Jaramillo. 2001. Community Structure of The Intertidal Meiofauna Along Gradient of Morphodynamic Sandy Beach Types in Southern Chile. Rev. Chil. Hist. Nat. 74: 1-19. doi: 10.4067/S0716-078 X2001000400015

Septiani, E.S., Setyawati, T.R. \& Yanti, A.H. 2013. Kualitas Perairan Sungai Kapuas Kota Sintang Ditinjau dari Keanekaragaman Makrozoobentos, Protobiont. 2(2):70-74. 
Setiawan, H. 2014. Pencemaran Logam Berat Perairan Kota Makassar dan Upaya Penanggulangannya. Eboni. 11(1):1-13.

Silence, J., Polk, P.H. \& Fiers, F. 1993. Influence of macrofauna on the vertical distribution of meiobenthos in an Avicenniamangala, Gazi Bay, Kenya. Belg. J., Zool. 123(suppl.1): 67.
Werorilangi, S., Tahir, A., Noor, A., Samawi, M.F. \& Faizal A. 2011. Spatial distribution of total metal and its fractions in coastal sediment of Makassar, Proc. Nat. Conf. Ind. Oceanolog. Ass. p:1-18 